\title{
ASI EKSKLUSIF DENGAN PERTUMBUHAN DAN PERKEMBANGAN BAYI USIA 1-6 BULAN
}

\author{
Siti Maemunah ${ }^{1}$, Ria Setia Sari ${ }^{2}$ \\ 1,2 Prodi Ilmu Keperawatan STIKes Yatsi, Tangerang \\ Jl. Aria Santika No. 40A, RT 005/RW011 Margasari, Kec. Karawaci, Kota Tangerang, \\ Banten, Indonesia \\ sitimayf2@gmail.com
}

\begin{abstract}
Abstrak
Tumbuh kembang bayi sebagian besar ditentukan oleh seberapa banyak ASI yang dikonsumsi bayi. Bayi yang tidak diberi ASI eksklusif memiliki resiko lebih tinggi mengalami pertumbuhan dan perkembangan yang kurang optimal. Tujuan penelitian ini untuk mengetahui hubungan ASI Eksklusif dengan tumbuh kembang bayi usia 1-6 Bulan. Penelitian ini menggunakan desain penelitian korelasional dengan pendekatan studi cross sectional dengan sampel penelitian sebanyak 100 responden diambil dengan teknik simple random sampling. Untuk mengumpulkan data yang relevan, maka peneliti menggunakan instrument berupa timbangan berat badan, meteran, grafik berat badan/tinggi badan dan formulir Denver II. Untuk membuktikan adanya hubungan antara variabel tersebut digunakan uji statistik Chi Square. Hasil penelitian memberi gambaran bahwa bayi usia 1-6 bulan di Wilayah Kerja Puskesmas Citangkil Kota Cilegon mayoritas diberi ASI Eksklusif (78\%), mayoritas tumbuh dengan status gizi baik $(83 \%)$ dan mayoritas memiliki perkembangan normal (85\%). Ada hubungan antara pemberian ASI Eksklusif dengan pertumbuhan bayi usia $1-6$ bulan (p value : 0,000) dan ada hubungan antara pemberian ASI Eksklusif dengan perkembangan bayi usia 1 6 bulan ( $\mathrm{p}$ value : 0,000). Diharapkan pihak puskesmas Meningkatkan kegiatan-kegiatan yang mendukung peningkatan cakupan ASI Eksklusif dan keberhasilan pemberian ASI Eksklusif, seperti memperbanyak program penyuluhan kepada masyarakat mengenai pentingnya pemberian ASI secara eksklusif.
\end{abstract}

Kata kunci : bayi 1-6 bulan, ASI Eksklusif, pertumbuhan, perkembangan.

\begin{abstract}
The baby's growth and development is largely determined by how much milk the baby consumes. Babies who are not exclusively breastfed have a higher risk of experiencing less than optimal growth and development. The purpose of this study was to determine the relationship between exclusive breastfeeding and the growth and development of infants aged 1-6 months. This study uses a correlational research design with a cross sectional study approach with a research sample of 100 respondents taken by simple random sampling technique. To collect relevant data, the researchers used instruments in the form of weight scales, meters, weight/height charts and the Denver II form. To prove the existence of a relationship between these variables, Chi Square statistical test was used. The results of the study illustrate that infants aged 1-6 months in the Cilegon City Health Center Work Area are mostly exclusively breastfed (78\%), the majority grow up with good nutritional status (83\%) and the majority have normal development (85\%). There is a relationship between exclusive breastfeeding and the growth of infants aged $1-6$ months ( $p$ value: 0.000) and there is a relationship between exclusive breastfeeding and the development of infants aged 1 - 6 months ( $p$ value: 0.000). It is hoped that the puskesmas will increase activities that supports increasing the coverage of exclusive breastfeeding and the success of exclusive breastfeeding, such as increasing outreach programs to the community about the importance of exclusive breastfeeding.
\end{abstract}

Keywords: baby 1-6 months, exclusive breastfeeding, growth, development.

\section{PENDAHULUAN}

Kodrat sebagai ibu adalah memberi air susu pada bayinya, hal tersebut adalah sesuatu kewajiban mulia untuk seorang ibu demi tumbuh kembang dan keselamatan bayi kelak di masa yang akan datang. Dengan diberikaan

Corresponding author:

Siti Maemunah

sitimayf2@gmail.com 
ASI secara Eksklusif 1 sampai usia 6 bulan bayi bisa terlindungi penyakit-penyakit yang bisa menyebabkan kematian pada bayi. Selain bermanfaat pada bayi, dengan memberikan ASI secara Eksklusif juga bermanfaat pada ibu, seperti mengurangi perdarahan setelah persalinan, mengurangi resiko terkena kanker payudara atau kanker rahim. Namun demikian, saat ini di dunia diperkirakan sebanyak $85 \%$ perempuan tidak memberikan ASI pada bayinya dengan optimal (Widodo, 2011).

Data United Nations Children's Fund (UNICEF) tahun 2017 mencatat di seluruh dunia hanya 38 persen bayi usia kurang dari 6 bulan yang mendapat ASI secara Eksklusif, di tahun 2019 mengalami penurunan kembali menjadi 36 persen. Cina sebagai salah satu negara yang memiliki populasi penduduk terbesar, cakupan keberhasilan pemberian ASI secara Eksklusif hanya sebesar 28 persen. Menurut data UNICEF, tiga negara dengan cakupan pemberian ASI terendah di dunia adalah Negara Somalia, Negara Chad, dan Negara Afrika Selatan (WHO, 2020).

Negara Republik Indonesia, anjuran atau himbauan untuk memberikan ASI secara Eksklusif diatur dalam PP RI No. 33 Tahun 2012 yang menyatakan bahwa ibu wajib memberikan ASI secara Eksklusif pada bayinya hingga usia 6 bulan. Namun realisasinya masih sangat kurang. Menurut riset kesehatan dasar tahun 2018, bahwa cakupan ASI hanya sebesar 37,3\%, menurun dari hasil Riskesdas tahun 2013 sebesar 54,3\%. Hasil tersebut juga menggambarkan adanya penurunan cakupan ASI Eksklusif berdasarkan hasil Survei Demografi Kesehatan Indonesia (SDKI) tahun 2017 yang mencatat cakupan ASI Eksklusif bayi usia kurang dari enam bulan di Indonesia sebesar 52\% (SDKI, 2017). Persentase pemberian ASI ekslusif secara nasional diperoleh angka tertinggi terdapat pada Provinsi Babel (56,7\%), persentase terendah terdapat pada Provinsi NTB (20,3\%). Cakupan ASI Eksklusif di Provinsi Banten sebesar 35\% (Kemenkes RI, 2018).

Terdapat berbagai alasan atau faktor yang membuat ibu tidak memberi ASI ekslusif pada bayinya. Menurut Penelitian Umami, (2018) dan Kinasih (2017) faktor yang mempengaruhi pola pemberian ASI Eksklusif adalah dukungan keluarga. Menurut penelitian Fabriani et al. (2016) faktor yang mempengaruhi pola pemberian ASI Eksklusif adalah psikis ibu, dukungan keluarga, pengetahuan tentang ASI eksklusif, dan konseling ASI usia ibu. Sedangkan menurut penelitian Nasution et al. (2016), faktor yang mempengaruhi pola pemberian ASI Eksklusif adalah pendidikan, pengetahuan dan dukungan suami.

Rendahnya cakupan ASI Eksklusif dapat mengganggu pertumbuhan dan perkembangan bayi. Gotia (2016) menyatakan bahwa untuk meningkatkan pertumbuhan dan perkembangan bayi, pemberian ASI Eksklusif merupakan kewajiban yang harus dilakukan. ASI Eksklusif adalah makanan paling baik untuk bayi, ASI memiliki kandungan zat gizi dengan jumlah serta komposisi yang tepat dan sangat dibutuhkan dalam tumbuh kembang bayi.

Secara fisiologi bayi usia 0-6 bulan adalah kelompok resiko tinggi terhadap gangguan tumbuh kembang, ibu yang tidak memberikan bayinya secara ASI eksklusif dapat mengakibatkan pertumbuhan dan perkembangannya kurang optimal (Widodo, 2011). Tumbuh kembang bayi dan balita mayoritas tergantung pada jumlah ASI yang diperolehnya, termasuk enerji dan zat gizi lainnya yang terkandung dalam ASI tersebut. ASI dapat menycakupi kebutuhan pertumbuhan dan perkembangan usia 6 bulan. Pemberian ASI tanpa peberikan makanan lain selama 6 bulan disebut dengan menyusui secara eksklusif (Roesli, 2017).

Hasil observasi data di Puskesmas Citangkil, diketahui pada tahun 2020 angka kejadian stuntung adalah $0.7 \%$ mengalami peningkatan dari tahun 2019 yang mencatat kejadian stunting sebesar $0,5 \%$. Pada tahun 2020 didapatkan jumlah kunjungan bayi sebanyak 216 bayi, dengan 128 bayi diberi ASI eksklusif dan 88 bayi diberi ASI non eksklusif (dicampur dengan susu formula). Dari data tersebut diketahui cakupan ASI di Puskesmas Citangkil tahun 2020 hanya sebesar 59,2\% masih kurang dari target pemerintah dalam PP No. 33 tahun 2012 yang memiliki target sebanyak 85 persen bayi diberi ASI secara Eksklusif hingga usia 6 bulan. Selain itu, diketahui bahwa dari 216 bayi tersebut sebanyak 193 bayi mengalami tumbuh kembang baik dengan riwayat ASI sebanyak 118 bayi diberikan ASI Eksklusif dan 75 bayi diberikan susu formula. Kemudian terdapat 23 bayi mengalami tumbuh kembang kurang baik, 
yaitu 13 bayi terhambat pada perkembangan motorik halus (kekuatan otot tangan lemah, tidak mampu menggenggam benda dengan baik) dengan riwayat ASI 7 bayi diberikan susu formula dan 6 bayi diberikan ASI Eksklusif, 6 bayi terhambat pada perkembangan bahasa dengan riwayat ASI 4 bayi diberikan susu formula, 2 bayi diberikan ASI ekslusif dan 4 bayi mengalami gangguan pada perkembangan motorik kasar (belum dapat menegakkan kepalanya dengan stabil, belum bisa berguling secara perlahan) dengan riwayat ASI 2 bayi diberikan susu formula dan 2 bayi diberikan ASI Eksklusif.

Berdasarkan fenomena tersebut, penulis tertarik mengadakan penelitian tentang "Hubungan ASI Eksklusif dengan Pertumbuhan dan Perkembangan bayi Usia 1-6 Bulan".

\section{METODE PENELITIAN}

Penelitian ini merupakan jenis penelitian deskriptif korelasional dengan desain penelitian cross sectional. Populasi penelitian ini ialah seluruh bayi usia $1-6$ bulan di Wilayah Kerja Puskesmas Citangkil Kota Cilegon. Berdasarkan data rekam medis Puskesmas Citangkil diketahui bahwa pada periode bulan Juni tahun 2021 terdapat bayi usia 1-6 bulan sebanyak 132 bayi. Sampel diambil dengan teknik random sampling. Berdasarkan perhitungan rumus didapatkan jumlah sampel sebanyak 100 responden.

Kriteria sampel dalam penelitian ini adalah sebagai berikut:

1) Bayi dalam keadaan sehat

2) Keluarga tidak bersedia mengikuti penelitian

Untuk mengumpulkan data yang relevan, peneliti menggunakan instrumen berupa timbangan berat badan, meteran, grafik berat badan/tinggi badan dan formulir Denver II. Untuk membuktikan hipotesis penelitian digunakan uji statistik Chi Square.

Dalam melakjukan penelitian ini, peneliti berpedoman pada etika penelitian sebagai berikut:

1. Menghormati harkat serta martabat manusia

2. Menghormati privasi atau kerahasiaan subjek penelitian Keadilan dan inklusifitas

3. Memperhitungkan dari segi manfaat dan kerugian
HASIL

1. Hasil Analisis Univariat

Tabel 1

Gambaran ASI Eksklusif pada Bayi Usia 1-6 Bulan

\begin{tabular}{ccc}
\hline ASI Eksklusif & $(\mathbf{n})$ & $\mathbf{( \% )}$ \\
\hline Tidak & 22 & 22,0 \\
Iya & 78 & 78,0 \\
\hline Total & $\mathbf{1 0 0}$ & $\mathbf{1 0 0}$ \\
\hline
\end{tabular}

Berdasarkan Tabel 1 diketahui bahwa dari dari 100 bayi 1-6 bulan di Puskesmas Citangkil Kota Cilegon sebagian besar (78\%) atau sebanyak 78 bayi diberikan ASI Eksklusif.

Tabel 2

Gambaran Pertumbuhan Bayi Usia 1-6 Bulan

\begin{tabular}{ccc}
\hline Pertumbuhan & $(\mathbf{n})$ & $(\boldsymbol{\%})$ \\
\hline Gizi Kurang & 17 & 17,0 \\
Gizi Baik & 83 & 83,0 \\
\hline Total & $\mathbf{1 0 0}$ & $\mathbf{1 0 0}$ \\
\hline
\end{tabular}

Berdasarkan Tabel 2 diketahui bahwa dari 100 bayi 1-6 bulan di Puskesmas Citangkul Kota Cilegon, sebagian besar (83\%) atau sebanyak 83 bayi tumbuh dengan status gizi baik.

Tabel 3

Gambaran Perkembangan Bayi Usia 1-6 Bulan

\begin{tabular}{ccc}
\hline Perkembangan & $(\mathbf{n})$ & $(\boldsymbol{\%})$ \\
\hline Suspek & 15 & 15,0 \\
Normal & 85 & 85,0 \\
\hline Total & $\mathbf{1 0 0}$ & $\mathbf{1 0 0}$
\end{tabular}

Berdasarkan Tabel 3 diketahui bahwa dari 100 bayi usia 1-6 bulan di Wilayah Kerja Puskesmas Citangkul Kota Cilegon, sebagian besar $(85 \%)$ atau sebanyak 85 bayi memiliki perkembangan normal.

\section{Hasil Analisis Bivariat}

Tabel 4

Hubungan ASI Eksklusif dengan Status Gizi Bayi Usia 1-6 Bulan

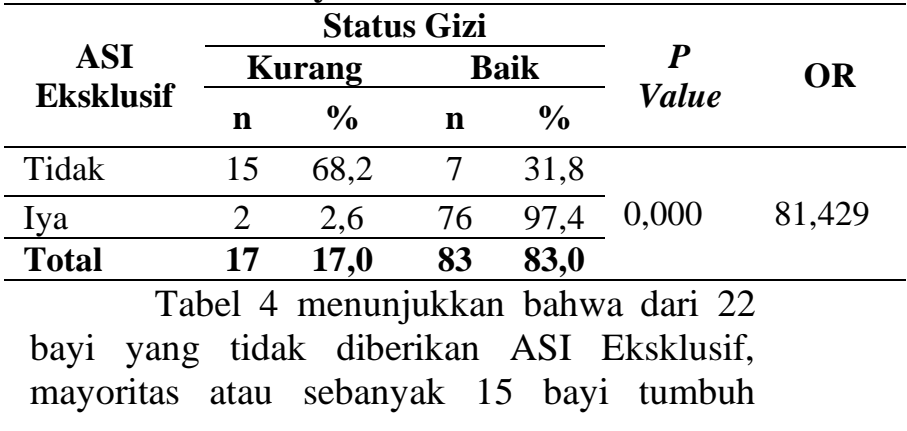


dengan status gizi kurang $(68,2 \%)$. Sedangkan dari 78 bayi yang diberikan ASI Eksklusif, hanya terdapat 2 bayi yang tumbuh dengan status gizi kurang $(2,6 \%)$.

Hasil uji statistik diperoleh nilai $\mathrm{p}=$ 0,000 , sehingga bisa disimpulkan ada hubungan yang signifikan antara ASI Eksklusif dengan pertumbuhan bayi usia 1-6 bulan. Hasil analisis juga diperoleh nilai $\mathrm{OR}=81,429$, hal tersebut berarti bahwa bayi 1-6 bulan yang tidak diberi ASI Eksklusif beresiko 81,429 kali lebih besar untuk tumbuh dengan status gizi kurang dibanding dengan bayi 1-6 bulan yang diberi ASI Eksklusif.

\section{Tabel 5}

Hubungan ASI Eksklusif dengan Perkembangan Bayi Usia 1-6 Bulan

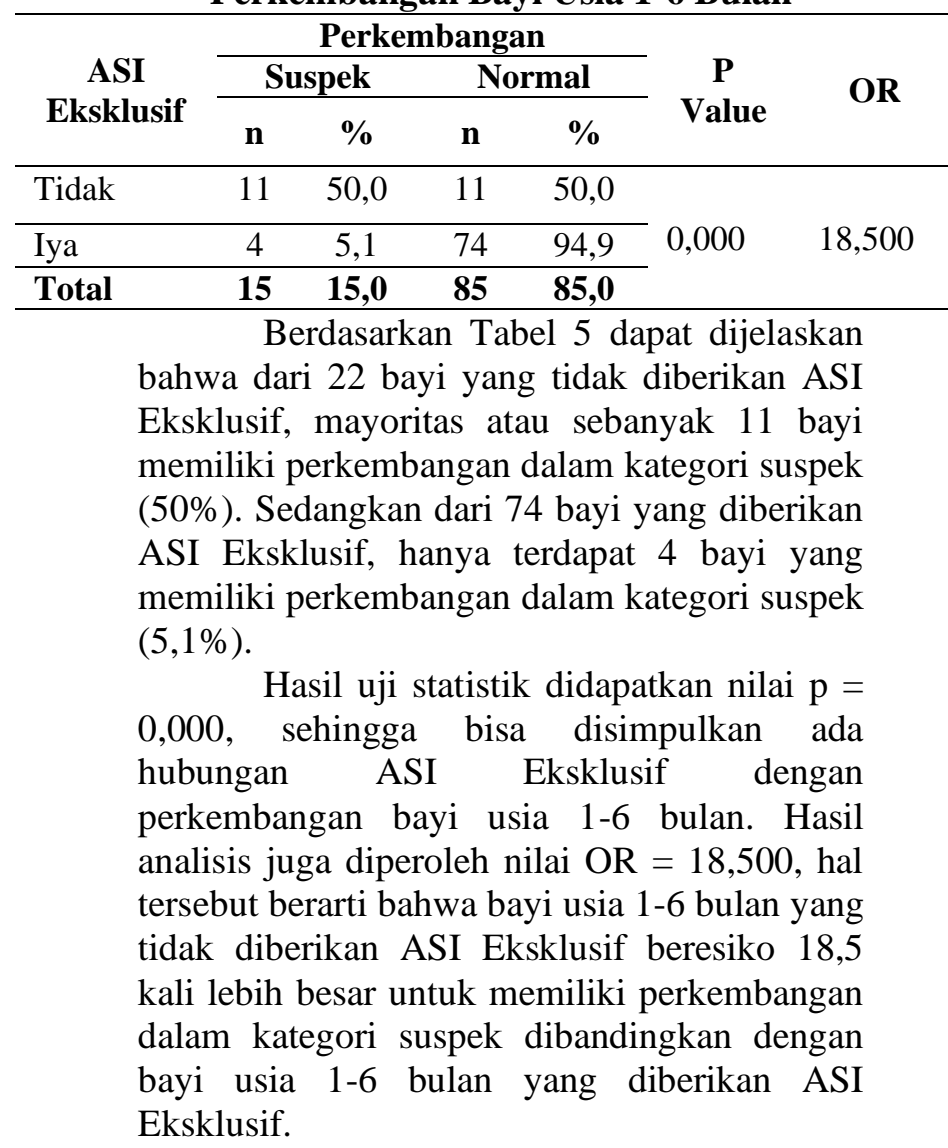

\section{PEMBAHASAN}

\section{Gambaran ASI Eksklusif pada Bayi Usia 1-6 Bulan}

ASI merupakan suatu emulsi lemak dalam larutan protein, laktosa dan garam organik yang diproduksi kelenjar payudara ibu, yang dipersiapkan untuk makanan bayi. Pemberian ASI Eksklusif yaitu selama 6 bulan bayi hanya diberi ASI, tanpa ditambah cairan atau makanan lain seperti susu formula, air, madu, jeruk, teh, atau makanan padat seperti bubur susu, pisang, nasi tim, biskuit dan bubur nasi (Kristiyanasari, 2011). Hasil penelitian menggambarkan bahwa sebagian besar bayi usia 1-6 bulan di Wilayah Kerja Puskesmas Citangkil Kota Cilegon diberikan ASI secara Eksklusif (78\%).

Hasil penelitian ini menunjukkan cakupan pemberian ASI Eksklusif di Wilayah Kerja Puskesmas Citangkil Kota Cilegon cukup tinggi, namun masih di bawah target dari pemerintah yaitu cakupan ASI sebesar 100\%. Seperti yang ditegaskan dalam pasal 6 PP no. 33 tahun 2012 yang menyatakan bahwa setiap ibu yang melahirkan harus memberikan ASI eksklusif kepada bayi yang dilahirkannya.

Yahya (2017) menyatakan bahwa ASI merupakan cairan terbaik yang diciptakan oleh Allah untuk memenuhi kebutuhan gizi bayi dan melindungi serta melawan dari serangan penyakit. ASI memiliki keseimbangan terbaik zat-zat gizi yang dibutuhkan bayi dan memiliki bentuk paling baik mudah dicerna oleh tubuh bayi. ASI juga mengandung banyak sari-sari makanan yang bisa mempercepat pertumbuhan sel-sel otak dan perkembangan sistem saraf. ASI sangat penting bagi bayi dan minimal harus diberikan sampai usia 2 tahun.

Hasil penelitian juga menunjukkan bahwa masih terdapat sebanyak $22 \%$ bayi tidak diberikan ASI secara eksklusif. Hal itu sebenarmya sangat disayangkan, mengingat manfaat ASI yang sangat dibutuhkan bayi. Bayi yang tidak diberi ASI rawan mengalami gangguan pertumbuhan dan perkembangan, dan rawan terhadap seranggan penyakit. Selain mengandung zat-zat gizi yang seimbang dan terbaik dan tidak terdapat pada makanan lainnya, ASI juga memiliki nilai ekonomis yang bisa menghemat pengeluaran ibu dibandingkan dengan harus membeli susu formula yang jelas tidak lebih baik dibandingkan ASI. Widodo (2011) menyatakan bahwa secara fisiologis bayi umur 0-6 bulan adalah kelompok yang paling rawan terhadap gangguan pertumbuhan dan perkembangan, sehingga dibutuhkan ASI 
Eksklusif untuk menjaga pertumbuhan dan perkembangannya tetap optimal. Pertumbuhan dan perkembangan bayi dan balita sangat tergantung pada jumlah ASI yang dikonsumsinya. ASI bisa mencukupi kebutuhan pertumbuhan dan perkembangan usia bayi 0-6 bulan .

\section{Gambaran Pertumbuhan Bayi Usia 1-6 Bulan}

Hasil penelitian menunjukkan bahwa mayoritas bayi usia 1-6 bulan di Wilayah Kerja Puskesmas Citangkul Kota Cilegon tumbuh dengan status gizi baik (83\%).

Soetjiningsih (2015) menjelaskan bahwa yang dimaksud pertumbuhan adalah perubahan yang sifatnya kuantitatif, seperti bertambanya ukuran, jumlah, dimensi pada tingkat sel organ, ataupun individu. Anak bukan hanya bertambah besar secara fisik namun juga ukuran serta struktur organorgan tubuh dan otak.

Narendra (2015) menjelaskan bahwa ciri dari pertumbuhan antara lain adalah perubahan ukuran fisik, misalnya tinggi badan, berat badan, lingkar lengan, lingkar kepala dan lingkar dada. Perubahan proposi fisik atau organ manusia yang muncul dimulai dari konsepsi hingga dewasa. Hilangnya ciri-ciri lama seperti kelenjar timus atau lepasnya gigi susu. Munculnya ciri atau tanda baru yang mengikuti proses kematangan, seperti tumbuhnya rambut.

Hasil penelitian juga masih ditemukan sebanyak $17 \%$ bayi usia 1-6 bulan memiliki pertumbuhan kurang baik atau dalam kategori kurus. Hal tersebut jika tidak segera mendapat penanganan yang baik bisa mempengaruhi perkembangan anak di masa depan. Soetjiningsih (2015) menjelaskan bahwa pada anak usia kurang dari satu tahun, pertumbuhannya sangat bergantung pada perawatan dan pengasuhan orang tua. Kebutuhan dasar utama yang diperlukan anak untuk tumbuh dengan optimal diantaranya kebutuhan pangan (gizi) dan perawatan kesehatan dasar seperti pemberian ASI dan imunisasi. Soetjiningsih (2015) juga menyatakan bahwa faktor terpenting yang harus dipenuhi untuk tumbuh kembang anak agar optimal adalah faktor pangan atau gizi dan ASI sangat berpengaruh terhadap pertumbuhan anak.

\section{Gambaran Perkembangan Bayi Usia 1-6 Bulan}

Perkembangan merupakan suatu perubahan bersifat kuantitatif, kualitatif serta meningkatnya kemampuan (skill), struktur dan fungsi tubuh yang lebih kompleks, melalui suatu pola teratur yang bisa diramalkan, hasil sebuah proses pematangan atau maturitas. Hasil penelitian menggambarkan sebagian besar bayi 1-6 bulan di Puskesmas Citangkul Kota Cilegon memiliki perkembangan normal (85\%).

Soetjiningsih (2015) menjelaskan bahwa perkembangan meliputi proses deferensiasi sel tubuh, jaringan tubuh, organ dan sistem organ yang berkembang sehingga bisa memenuhi fungsinya masing-masing. Termasuk perkembangan motorik, bahasa, kongnitif, emosi dan prilaku. Perkembangan adalah perubahaan dengan sifat terarah, terpadu dan progresif. Terarah dan terpadu menujukan ada hubungan antara perubahan yang terjadi saat ini dengan sebelumnya dan perubahan berikutnya. Progresif berarti perubahan memiliki arah maju ke depan tidak mundur kebelakang.

Ciri dari suatu perkembangan antara lain yaitu melibatkan suatu proses pertumbuhan dan perubahan fungsi, misalnya perkembangan sistem reproduksi yang diikuti perubahan fungsi dari alat kelamin. Mempunyai tahapan berurutan, seperti perkembangan kemampuan dari melakukan hal sederhana menjadi bisa melakukan hal kompleks. Mempunyai kecepatan perkembangan yang berbeda pada setiap individu. Bisa menentukan pertumbuhan pada tahap berikutnya (Narendra, 2015).

Dalam penelitian ini perkembangan bayi usia 1-6 bulan diukur menggunakan skrining perkembangan Denver II yang merupakan sebuah metode skrining terhadap kelainan perkembangan anak. Dalam penggunaan Denver II, perkembangan anak dinilai dengan cara membandingkan kemampuan perkembangan anak satu dengan anak 
lainnya yang seumuran (Soetjiningsih, 2015).

Hasil penelitian ini juga menunjukkan bahwa masih terdapat sebanyak $15 \%$ bayi 1-6 bulan memiliki perkembangan dalam kategori suspek. Gambaran perkembangan yang kurang baik pada bayi usia 1-6 bulan yang ditemukan saat penelitian diantaranya pada perkembangan motorik halus, seperti kekuatan otot tangan lemah dan tidak mampu menggenggam benda dengan baik, pada perkembangan bahasa, dan pada perkembangan motorik kasar seperti belum belum bisa berguling secara perlahan atau mendongakkan kepala.

\section{Hubungan ASI Eksklusif dengan Pertumbuhan Bayi 1-6 Bulan}

Hasil analisis menunjukkan bahwa dari pada bayi yang tidak diberikan ASI Eksklusif, mayoritas tumbuh dengan status gizi kurang $(68,2 \%)$. Sedangkan pada bayi yang diberikan ASI Eksklusif, sangat sedikit bayi yang tumbuh tumbuh dengan status gizi kurang $(2,6 \%)$.

Dari hasil tersebut terlihat bahwa bayi 1-6 bulan yang diberikan ASI Eksklusif lebih banyak yang tumbuh normal dibandingkan pada bayi 1-6 bulan yang tidak diberikan ASI Eksklusif. Hasil uji statistik didapatkan nilai $\mathrm{p}=0,000$, sehingga bisa disimpulkan ada hubungan antara ASI Eksklusif dengan pertumbuhan bayi usia 1-6 bulan. Hasil analisis juga diperoleh nilai $\mathrm{OR}=81,429$, hal tersebut menunjukkan bayi usia 1-6 bulan yang tidak diberikan ASI Eksklusif beresiko 81,429 kali lebih besar untuk tumbuh dengan status gizi kurang dibandingkan dengan bayi 1-6 bulan yang diberikan ASI Eksklusif.

Hasil ini sesuai dengan teori Narendra (2015) yang menjelaskan bahwa bayi yang mendapatkan ASI Eksklusif akan berpotensi mengalami pertumbuhan yang lebih baik. Lebih jauh dijelaskan bahwa bayi dengan ASI Eksklusif cenderung tumbuh normal karena ASI mengandung zat-zat penting yang dibutuhkan oleh pertumbuhan bayi, seperti nutrisi, hormon, faktor kekebalan, faktor pertumbuhan, dan anti inflamasi.
Hasil penelitian ini juga sejalan dengan hasil penelitian Asdiningrum (2019) di Yogyakarta yang mendapatkan hasil ada hubungan antara pemberian ASI Eksklusif dengan pertumbuhan bayi usia 69 bulan ( $\mathrm{p}$ value $=0,003$ ). Pada bayi yang diberikan ASI Eksklusif menunjukkan sebanyak $97,7 \%$ bayi tumbuh normal, sedangkan pada bayi yang tidak mendapatkan ASI Eksklusif sebanyak 33,3\% bayi tumbuh dengan tidak normal. Demikian juga hasil penelitian Febriani (2019) di Lampung yang menunjukkan bahwa ada hubungan antara pemberian ASI Eksklusif dengan tumbuh kembang bayi usia 6 bulan. Dalam penelitian tersebut didapatkan sebanyak $83,3 \%$ bayi yang diberikan ASI Eksklusif mengalami tumbuh kembang yang sesuai.

Menurut peneliti, adanya hubungan antara pemberian ASI Eksklusif dengan pertumbuhan bayi usia 1-6 bulan disebabkan ASI adalah sumber makanan utama bagi bayi yang memiliki kandungan nutrisi lengkap yang dibutuhkan dalam pertumbuhan bayi. Kandungan zat gizi pada ASI lebih baik dan mencukupi kebutuhan pertumbuhan bayi dibandingkan dengan susu formula.

\section{Hubungan ASI Eksklusif dengan Perkembangan Bayi 1-6 Bulan}

Hasil analisis menunjukkan bahwa pada bayi yang tidak diberikan ASI Eksklusif, mayoritas bayi memiliki perkembangan dalam kategori suspek (50\%). Sedangkan pada bayi yang diberikan ASI Eksklusif hanya sedikit bayi yang memiliki perkembangan dalam kategori suspek $(5,1 \%)$.

Dari hasil tersebut terlihat bahwa bayi 1-6 bulan yang diberikan ASI Eksklusif lebih banyak yang memiliki perkembangan normal dibandingkan pada bayi yang tidak diberi ASI Eksklusif. Hasil uji statistik diperoleh nilai $\mathrm{p}=0,000$, sehingga bisa disimpulkan ada hubungan antara ASI Eksklusif dengan perkembangan bayi 1-6 bulan di Puskesmas Citangkil Kota Cilegon tahun 2021. Hasil analisis juga diperoleh nilai $\mathrm{OR}=18,500$, hal tersebut berarti bahwa bayi usia 1-6 bulan yang tidak diberikan ASI Eksklusif beresiko 18,5 kali lebih 
besar untuk memiliki perkembangan dalam kategori suspek dibandingkan dengan bayi usia 1-6 bulan yang diberikan ASI Eksklusif.

Hasil penelitian ini sesuai dengan teori Widodo (2011) yang menjelasakan bahwa secara fisiologis bayi umur 0-6 bulan adalah kelompok yang paling rawan terhadap gangguan perkembangan. Ibu yang tidak memberikan bayinya ASI eksklusif dapat mengakibatkan perkembangan bayi kurang optimal. Roesli (2017) menambahkan bahwa perkembangan bayi dan balita sebagian besar ditentukan oleh jumlah ASI yang diperoleh, termasuk energi dan zat gizi lainnya yang terkandung dalam ASI. Ikatan Dokter Anak Indonesia (IDAI, 2013) menyatakan bahwa ASI mengandung laktosa, protein, lemak dan asam amino taurin yang sangat dibutuhkan dalam perkembangan otak. ASI juga banyak mengandung vitamin A yang bermanfaat untuk kesehatan mata serta mendukung dalam pembelahan sel dan meningkatkan kekebalan tubuh.

Hasil penelitian ini juga sejalan dengan hasil penelitian Bahrudin (2016) di RSUD Sidoarjo yang mendapatkan hasil bahwa pemberian ASI Eksklusif memiliki hubungan yang signifikan dengan perkembangan bayi umur 6 bulan sampai 1 tahun. Demikian juga dengan hasil penelitian Febriani (2019) di Lampung yang menunjukkan bahwa ada hubungan anatara pemberian ASI Eksklusif dengan tumbuh kembang bayi usia 6 bulan.

Menurut peneliti, adanya hubungan antara pemberian ASI Eksklusif dengan perkembangan bayi 1-6 bulan disebabkan ASI memiliki kandungan zat-zat yang mendukung perkembangan bayi lebih baik daripada yang ada pada susu formula. Sehingga bayi yang diberi ASI lebih besar peluangnya untuk berkembang secara optimal dibanding dengan bayi yang diberi susu formula. Pada bayi yang diberi susu formula akan kekurangan zat-zat yang mendukung perkembangannya sehingga beresiko perkembangannya menjadi tidak optimal.

\section{KESIMPULAN}

Pemberian ASI Eksklusif pada bayi usia 1
- 6 bulan di Puskesmas Citangkil Kota Cilegon sebesar $78 \%$, sebagian tumbuh dengan status gizi baik (83\%), sebagian besar memiliki perkembangan normal (85\%). Ada hubungan antara pemberian ASI Eksklusif dengan pertumbuhan bayi usia 1 - 6 bulan ( $\mathrm{p}$ value : $0,000)$ dan ada hubungan antara pemberian ASI Eksklusif dengan perkembangan bayi usia 1 - 6 bulan ( $\mathrm{p}$ value : 0,000).

Berdasar temuan dalam penelitian ini peneliti menyarankan pihak puskesmas untuk meningkatkan kegiatan-kegiatan yang mendukung peningkatan cakupan ASI Eksklusif dan keberhasilan pemberian ASI Eksklusif, seperti memperbanyak program penyuluhan kepada masyarakat mengenai pentingnya pemberian ASI secara eksklusif.

\section{DAFTAR PUSTAKA}

Asdiningrum. (2019). Hubungan Pemberian ASI Eksklusif dengan Pertumbuhan Bayi Usia 6-9 Bulan di Wilayah Kerja Puskesmas Jetis Kota Yogyakarta. Politeknik Kesehatan Kementerian Kesehatan Yogyakarta.

Bahrudin. (2016). Hubungan Pemberian Asi Eksklusif Dengan Perkembangan Bayi Usia 6 Bulan - 1 Tahun. Jurnal Penelitian Kesehatan Suara Forikes, VII, 2.

Fabriani, Rohsiswatmo, \& Hendarto. (2016). Faktor yang mempengaruhi pemberian ASI Eksklusif pada bayi cukup bulan yang dilakukan inisiasi menyusu dini (IMD). Sari Pediatri, 15(6), 1-9.

Febriani. (2019). Pemberian ASI Eksklusif dengan Tumbuh Kembang Bayi Usia 6 Bulan di Wilayah Kerja Puskesmas Wates Pringsewu Lampung. Wellness and Healthy Magazine.

Gotia. (2016). Survey faktor-faktor yang mempengaruhi pemberian ASI Eksklusif pada ibu post pertum di Puskesmas Alak Kota Kupang. Jurnal Keperawatan CHMK, 1(1), 1-5.

IDAI. (2013). Air Susu Ibu dan Peranannya dalam Pencegahan Obesitas. IDAI.

Peraturan Pemerintah Republik Indonesia 
Nomor 33 Tahun 2012 Tentang Pemberian Air Susu Ibu Eksklusif, (2012).

Kemenkes RI. (2018). Riset Kesehatan Dasar.

Kinasih. (2017). Pengaruh Dukungan Keluarga terhadap pemberian ASI Eksklusif di Puskesmas Wonosari I Kabupaten Gunung Kidul. Jurnal Poltekkes Kemenkes Yogyakarta.

Kristiyanasari. (2011). Asi, Menyusui \& Sadari. Nuha Medika.

Narendra. (2015). Standard Tubuh Kembang. Ikatan Dokter Indonesia.

Nasution, Liputo, \& Mahdawaty. (2016). Faktor-Faktor yang Berhubungan dengan Pola Pemberian ASI Eksklusif di Wilayah Kerja Puskesmas Bungus. Jurnal Kesehatan Andalas, 5(3), 1-5.

Roesli. (2017). ASI Eksklusif (2nd ed.). Trubus Agriwidya.
SDKI. (2017). Cakupan ASI Eksklusif di Indonesia.

Soetjiningsih. (2015). Tumbuh Kembang Anak. EGC.

Sugiyono. (2017). Metode Penelitian Kuantitatif, Kuyalitatif, dan $R \& D$. Alfabeta.

Supariasa. (2013). Penilaian Status Gizi (Edisi revi). EGC.

Umami. (2018). Faktor-faktor yang mempengaruhi pemberian ASI Eksklusif. Jurnal Kedokteran Diponegoro, 7(4), 111.

WHO. (2020). Global Strategy for Infant and Young Child Feeding.

Widodo. (2011). Asi Menyusui \& Sadari. Nuha Medika.

Yahya. (2017). Bayi Sehat Berkat ASI Eksklusif (E. 2 (ed.)). Trubus Argtiwidya. 